This item was submitted to Loughborough's Research Repository by the author.

Items in Figshare are protected by copyright, with all rights reserved, unless otherwise indicated.

\title{
Looking through a windscreen: managing the future of automobility
}

PLEASE CITE THE PUBLISHED VERSION

https://doi.org/10.1080/23800127.2020.1776510

PUBLISHER

Taylor \& Francis (Routledge)

VERSION

AM (Accepted Manuscript)

PUBLISHER STATEMENT

This is an Accepted Manuscript of an article published by Taylor \& Francis in Applied Mobilities on 18 July 2020, available online: http://www.tandfonline.com/10.1080/23800127.2020.1776510.

\section{LICENCE}

CC BY-NC-ND 4.0

\section{REPOSITORY RECORD}

Enoch, Marcus, and James Warren. 2020. "Looking Through a Windscreen: Managing the Future of Automobility". Loughborough University. https://hdl.handle.net/2134/12417437.v1. 


\section{Looking through a windscreen: managing the future of automobility}

6885/8182/8234/Applied Mobilities (2020)

F3/F4 Final Author Version (accepted) 17/02/2020.

Marcus ENOCH, Professor of Transport Strategy, Transport and Urban Planning

Group, School of Architecture, Building and Civil Engineering, Loughborough

University, Loughborough, LE11 3TU, UK. Email: m.p.enoch@lboro.ac.uk.

James P. WARREN, (corresponding author), Senior Lecturer in Design, Design Group, School of Engineering and Innovation, STEM, The Open University MK7 6AA, UK.

Email: james.warren@open.ac.uk.

Date of acceptance 30 April 2020.

Date of online publication 


\section{Looking through a windscreen: managing the future of automobility}

Global car ownership and usage have grown rapidly for several decades now and these trends look set to continue. For car users, the increased mobility afforded by the automobility system is largely welcomed despite the significant externalities produced. The windscreen is one location where controls on automobility are affixed by using artefacts such as paper discs, decals, stickers or digital devices. These artefacts, in turn, have significant meanings and symbolism on how users relate to their vehicles and how others attempt to control car ownership and use.

The aim of this paper is to examine how ownership and use are controlled currently, and to speculate on how they might be mapped in the future through a catalogue of windscreen-mounted artefacts. The artefacts have been sourced globally and were arranged according to the 'type' of control they were exerting. Artefact classification analysis shows that public policy instruments can be categorised according to informational, regulatory or economic control; the aspect being targeted; and the frequency and longevity of these interventions. Categories include agents and the focus of action through which a policy instrument is applied. Future trajectories are explored with respect to the role of clutter and the windscreen itself as morphing during possible shifts towards a paradigm of smarter mobility emphasising the importance of usership (not ownership), increasing digitalisation, increasing intelligence, less carbon intensity/electrification, and finally automation.

Keywords: futures, vehicle controls, windscreen, passenger cars, personal transport, artefacts, mobility regulation

\subsection{Introduction}

Car ownership and car-use have, for several decades now, represented an aspiration of a 
significant proportion of people worldwide, and consequently both have grown at a phenomenal rate ever since the successful adoption of the internal combustion engine at the end of the Nineteenth Century. Thus, as of 2015 there were 1.1 billion cars globally (Nitch-Smith, 2016), a figure which is set to rise to 2.0 billion by 2040 and then nearly double again to 2.9 billion by 2050 if current trends continue (Chamon et al, 2008).

In many ways the increase in mobility afforded by this is to be welcomed, most particularly for the individual motorist who typically benefit from being able to access far more opportunities than previously albeit many of these outcomes are unevenly distributed (Dant, 2017). However, at the societal level unconstrained car mobility can also lead to a range of economic, environmental and social dis-benefits including traffic congestion, unpredictable journey times, noise, air pollution, inefficient energy use, road traffic accidents, community severance, and worsening health outcomes (Douglas et al, 2011; Rydin, 2012). With more than 1 million killed each year in developing cities due to road deaths, Dennis and Urry (2009) deem the key commodity of desire - the car system - as 'sheer carnage' - or according to Böhm et al. (2006) as a mass 'accident'. In having attempted to balance these conflicting desires over many years, it has become increasingly clear to policy makers that the car will therefore need to be managed ever more assiduously as time goes by, and this will have significant impacts on how people, and in particular car drivers and owners, will relate to their vehicles (Dant, 2017; Docherty et al, 2018).

This paper characterises the windscreen and associated artefacts which represent both the individual motorist, as well as national and local level operators and road network manager who require badges to be placed on the vehicle. These items are based on a mixture of past, present and proposed policy mechanisms from around the world. The aim of the paper is to identify how car ownership and use are controlled currently, 
and to speculate on how the ways that cars might be used and managed in the future. It does not seek to explicitly on the effectiveness or acceptability of any of the policy instruments represented by the artefacts considered. Extensive evaluation of a range of transport instruments are made elsewhere, for example Santos et al (2010a, 2010b). The study focussed on windscreen-linked artefacts (i.e. physical items affixed to the car windscreen) as a way of capturing and categorising control over automobility. As noted by Dennis \& Urry $(2009$, p.59) “...the car system is a way of life, an entire culture. It has redefined movement, pleasure and emotion in the contemporary world, transforming the fitness landscape for all other mobility systems that have to find their place within a landscape predominantly sculpted by the car system.” This study treats the windscreen (or windshield) and the related items affixed to it as a sub-system of the car for investigation. The windscreen primarily acts as protective device from the outside world, but it also plays a key framing element as the driver's window into the world (Mauch \& Zeller, 2008), and as the view into the cockpit of the vehicle from those who are outside the car (Morse, 1998).

Although little has been written about the windscreen, there has been much work carried out on the views and vistas from the driver's position through the glass including diverse stories from Mauch \& Zeller's (2008) work which describe the importance of landscape and 'motorscape' to drivers in parks and on turnpikes, as well as their critical national importance, in time and space, for autobahn and motorway construction. The driver's gaze is a feature of many of these stories (see Dossman's entry, ibid p. 144, on German Democractic Republic) who emphasises that the highway system represents both a symbolic and functional system, usually represented in a highly stylised way emphasising perfection by blending serene landscapes with human derived freeways. Dossman states ...that once again that [these] artefacts do have 
politics, and politics do produce artefacts." In a similar mode we argue that those managing mobility use artefacts to control driver functionality by encouraging 'greener' or safer driving behaviour or by restricting access, limiting distances, or fuel use, whilst at the same time drivers utilise artefacts to display their personality (Gössling, 2017), or in some cases their loyalty to certain products, practices, or beliefs. There is also a body of work which has considered the importance of bumper stickers (Case, 1992; Doyle \& Tranter, 2015; Lloyd \& Fourt-Wells, 2018), which in some cases are affixed to the rear windscreen rather than the actual bumper or vehicle body. In this study a deliberate boundary was placed around the front (forward facing) windscreen partly in order to limit the number of objects but also to assist in framing the study from the driver's view and from the view of those outside the vehicle. This framing allows for the tensions between the driver and the outside world to be considered as viewed through the glass window.

\subsection{Classification of windscreen artefacts}

The most common approach in which public policy instruments can be categorised is to consider how they influence the behaviour of the target audience. Thus Etizoni (1961) notes that fundamentally there are three types of social control: coercion, economic assets and normative values, which Vedung (1998) translates into three categories of policy instruments, namely: regulation, economic assets and information otherwise known as sticks, carrots and sermons. Dodds (2013) outlines what these mean in practice, as follows:

- Regulatory measures can be absolute, conditional with exemptions, with permissions, or with obligation to notify, and hence include concessions, 
permits, licences, and authorisations and are 'enforced' through authority being applied on agents who are obligated to obey;

- Economic assets typically refer to cash-based instruments such as incentives, loans, taxes, charges and tariffs but could also include in-kind incentives or vouchers and work through a form of persuasion through economic self-interest.

- Information measures can involve a range of media once again to persuade people to 'do the right thing', this time often through social and/or economic levers.

Similarly, Conley and Tigar McLaren (2009) divide policy instruments according to whether they are essentially technical fixes and are aimed at the providers of transport infrastructure and vehicles, or social fixes, which are focussed on guiding the behaviour of individuals. Böhm et al (2006, p 7) note how the regime of automobility relies on 'a plethora of regulatory schemes, regulating speed, places, directions, parking places and priority'.

In terms of the aspects of urban transport to be targeted, Santos et al (2010a) provides a comprehensive list of measures aimed at addressing urban transport issues, though the classification system used - physical, soft and knowledge policies - is less useful in the context of this paper. More helpfully, May (1986) reports that "restraint methods can be categorised in terms of the stage in the process of car acquisition and use at which they are brought to bear" (p. 112). In essence, this concerns the aspect being targeted, and the frequency and longevity of these interventions. May (1986) suggests three categories, namely: controls that can be imposed according to the ownership of the car, on the destination (i.e. parking), or whilst the car is in use. Meanwhile from the perspective of frequency and longevity, some instruments are 'one off' measures implemented on the purchase of a vehicle for example or related to a driver passing a driving test, while 
others are applied on a far more frequent basis. And some instruments are limited to a fixed time period (perhaps for a year/month/day/hour), while others might be tripspecific.

It is useful to consider whether so-called demand side measures are adopted (which seek to influence the demand for transport on the assumption that the supply is too expensive, unpopular and time consuming to change) or whether supply side measures (whereby capacity is altered according to an independently variable demand for transport) can be applied (Enoch, 2012). Perhaps unsurprisingly given the context envisaged, i.e. where car ownership and use are growing rapidly, then the majority of controls aimed at the individual level will likely focus on the demand side. Yet it should also be noted that there are ways in which the efficiency of car use can be (and has been) enhanced. This can be done through increasing the amount of time during the day when the car is being used through carsharing/car club schemes (essentially short term car rental), and/or by increasing the occupancy of vehicles that are already making a trip through ridesharing/liftsharing programmes (see Chan and Shaheen, 2012; Shaheen and Cohen, 2013).

It is also helpful to understand the agents and routes through which a policy measure is applied. Enoch (2014) for example, finds five agent 'types' i.e. national government, local government, transport operator, mediating institution and individual which are generally arranged hierarchically, and ten potential 'delivery routes'. These routes range from national government imposing measures on each of the other agent types, whilst local authorities, transport operators and mediating organisations act on policies from higher up the chain and impose policies on those agents further down. Consequently, individuals (at the bottom of this chain), are affected by policies from all four higher agents. 
There is a huge body of literature that relates to criteria on which to evaluate the 'success' or otherwise of policy measures. In concisely summarising this, Ledbury et al (2006) proposes that policy measures need to be judged according to:

- Likely policy effectiveness against objectives and in terms of 'additionality' i.e. the impact 'over and above' do-nothing;

- Cost efficiency, in terms of Value for Money;

- Practicality, in terms of affordability, capacity to deliver, and enforceability;

- Public and political acceptability;

- Distribution, in terms of fairness between areas, groups, sectors etc and diversity;

- Legality; and

- Any side effects, for example on the environment, safety, employment, businesses, and competitiveness.

Finally, there are the practical elements that relate to how the measures are implemented, operated, enforced, and monitored (Enoch, 2012).

In building on this current literature, and in the light of the seemingly inexorable rise in car traffic, the thought emerged that vehicles will need to be managed ever more assiduously as time goes by, and this will have significant impacts on how individual people will relate to their vehicles. As Dant (2017, p.374) notes '...changes in western societies with less 'freedom' to drive due to road congestion, speed restrictions, and increasing capacity of the car to drive itself, we will have to look to other social and material arrangements to acquire status and pleasure." One way of illustrating the direction of travel that this implies, is by imagining how such a proliferation of new control mechanisms might directly impact on the typical motorist in a prosaic manner- 
that is via the car windscreen. The windscreen and our gaze through it act a crucial component within Urry's automobility complex (2004) and this window is likely to morph due to technology and other external impacts.

\subsection{Design and discovery: a collection of artefacts}

This paper therefore reports on the development of an artefact based exhibit which presents one vision of how the driving experience might change from the perspectives of the motorist and of road network and managers. This approach is in the found object practice or technique whereby researchers use objects to reinterpret values, metaphors or the status-quo through their outputs (Chilvers \& Glaves-Smith, 2015; Harrison \& Wood 2002). In this case, a car windscreen was obtained from a scrap dealer and then covered in a series of artefacts (decals, technological tools and so on) representing different available policy mechanisms that have been/are being/might be used to better manage car ownership and/or use (see Figure 1 for the nearly completed windscreen exhibited with many artefacts). Altogether 34 artefacts have been sourced directly or from contacts in 20 countries around the world and were arranged according to a set of criteria.

The criteria stem from our review of found objects, during which each item was carefully digitised and catalogued by origin, instrument objective, focus of action related to degree of formality and the agent that applies the represented policy instrument. The instrument objective sets out the goal or purpose underpinning the installation of the artefact as well as a brief description as to how this is achieved. The focus of action refers to whether the instrument is targeted at the occupant or at an aspect of the human-vehicle interface, in this case whether on vehicle ownership, usage, or parking. The timeframe of application ranges from the artefacts change continuously and in real time at one extreme through to trip-level items and ultimately instruments 
that last for the car's lifetime. The degree of formality attributes a score based on how formal the policy instrument is - from 1 (voluntary/highly informal) to 5 (mandatory/highly formal). Finally, the agent is the organisation responsible for implementing or applying the policy instrument. Organisations can include governments and their departments, employers, transport operators and other recognised authorities.

The authors deliberately placed each item within one of the three categories; we accept that other researchers may place specific items in different categories as this work is interpretive and adopts a post-positivist approach. Further examples of the role of found objects historically and their important role are summarised by Waldman (1992) and by Spencer (2002). Spencer notes that the use of everyday detritus has profound effect on why that one views life and Waldman (1992, p.8) asserts that ...collage...can thus be said to present a compelling historical record of our time." Part of work here is to create further discussions and thoughts about mobility through the use of assembled exhibits both for those researching, but also for those working around us, such as peers and students. The found object process followed a three step linear pathway of ideation, conceptualisation and formation (KhakZand \& Babaei, 2018). Figure 2 then shows the final product with all artefacts attached. 


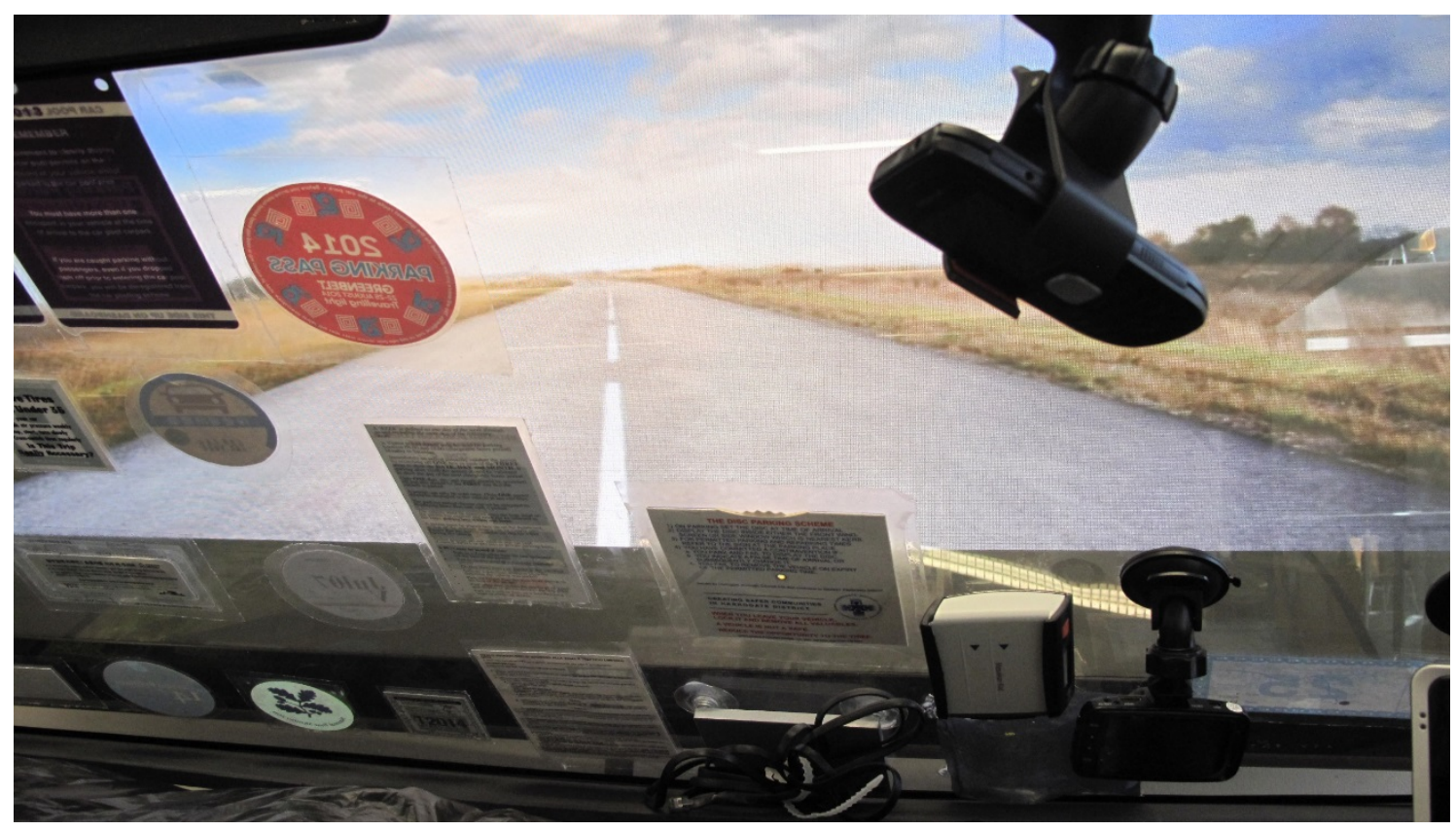

Figure 1: Artefacts displayed within a nearly completed windscreen showing a video mock-up of the road ahead (view from the driving position).

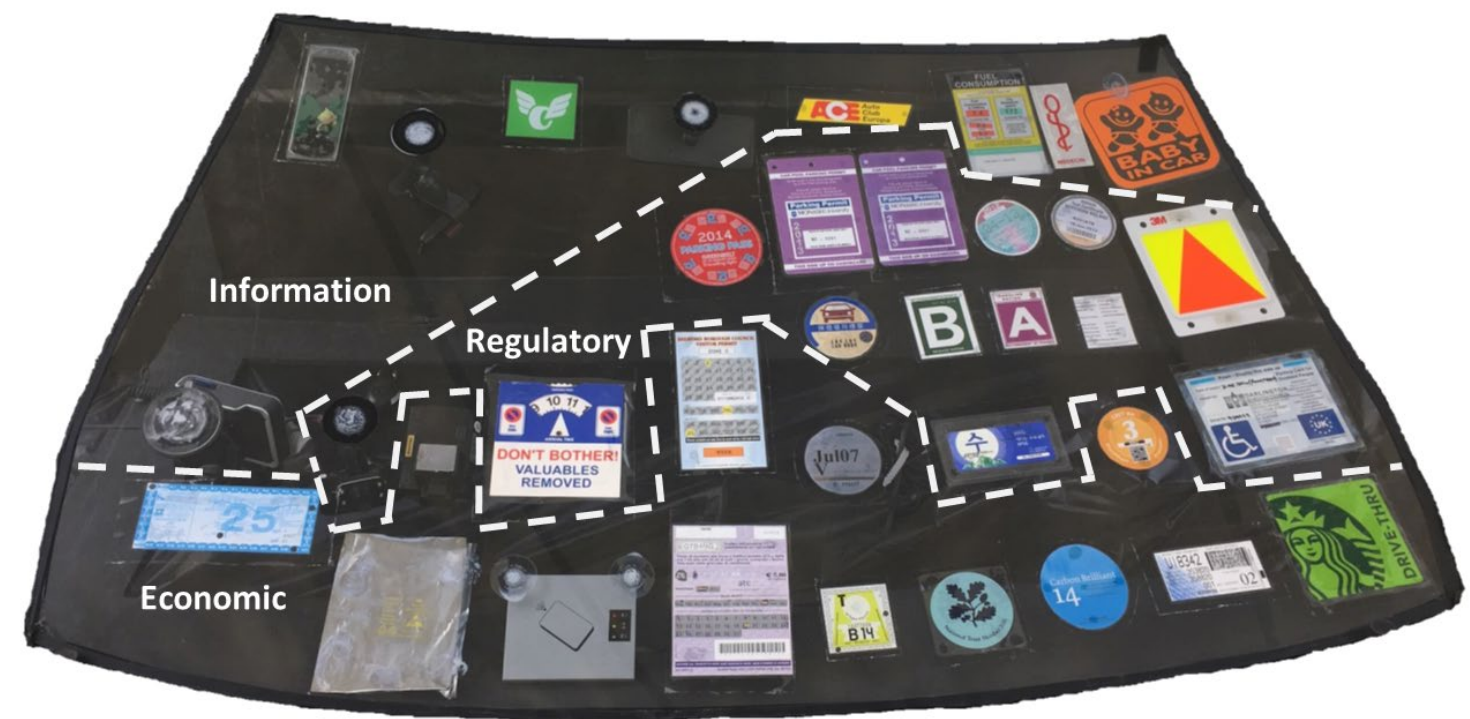

Figure 2: Artefacts displayed as a final exhibit (viewed from an external position) with an overlay of the boundaries for the three primary categories.

Firstly, in laying out the windscreen the artefacts were categorised from top to bottom by 'type' of instrument in terms of control mechanism employed (information, regulatory, economic) (see Figure 2). Secondly, they were then arranged according to 
whether the artefact was connected to the vehicle itself (shown on the left) or to the person/people in it (shown to the right). Thirdly, the vehicle-related measures are then arranged from dynamically-applied instruments (minute-by-minute) through less than daily (including trip-based measures), to daily, less than annual, to annual, and lastly to one off measures that would last the lifetime of the car (see Figure 3).

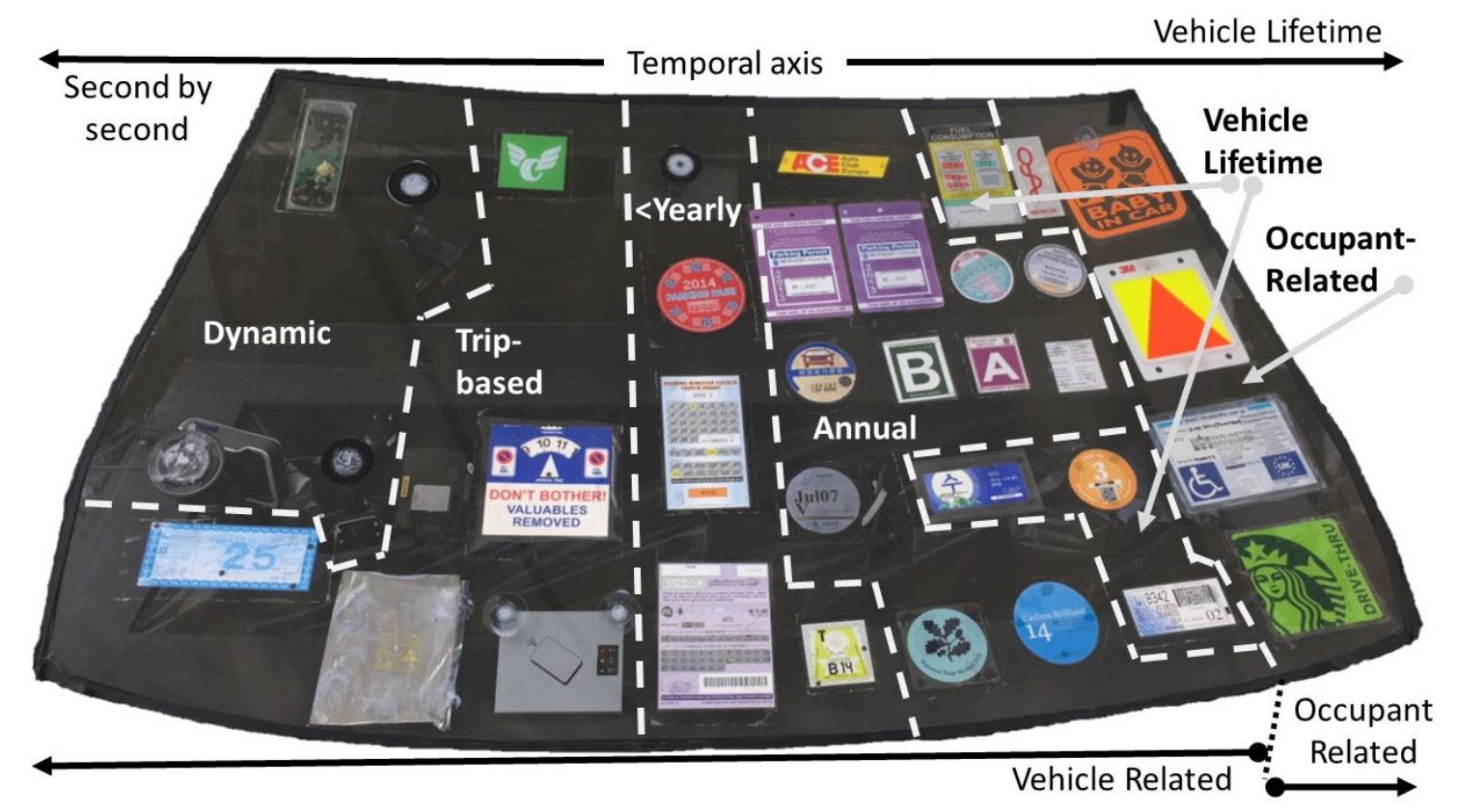

Figure 3: Overlay of an applied temporal dimension and the line of separation between vehicle-based and occupant-focussed artefacts and the linking relationship shown for each the artefacts.

Figure 4 displays the key labels for each of the artefacts which are used within Tables 1 , 2 and 3. The artefacts are discussed in detail in the following section. It should be noted that a very small unadorned slot remains in place through which could allow the driver to see the road. This lack of space for viewing links with our thought processes around what kinds of windscreens might exist in the future, as well as highlighting the ideas of control and how control might be carried out in with autonomous cars. This deliberate overload of artefacts also emphasises the relevance of 'clutter' as an associated theme. We also considered collecting further samples to create a much more cluttered collage, 
for example with layers of hundreds of items using a poster format, but it was felt that using a transparent medium to adhere all the items on was effective as it allows the viewer to see through the glass, and it also allows the viewers to see both sides of each artefact when relevant. Our observations of vehicle windscreens, mainly in the UK, United States and much of Western Europe found that typically not more than 2-3 stickers on windscreens were present. In some countries the placement of the sticker is tightly regulated, see for example the motorway sticker for Switzerland (Swiss FAC, 2020) or similar to the UK which has strict legislation on ensuring the driver's view is not obscured by "stickers, pennants, satellite navigation monitors or decorations" (TSO, 2010). This led us to retaining at least some space for the driver to be able to see the road ahead, but this is clearly much less than that of a typical or normal windscreen and would be illegal in the UK, as well as in many other countries (see Community Directive $77 / 649,81 / 643,88 / 366,90 / 630$ for further details).

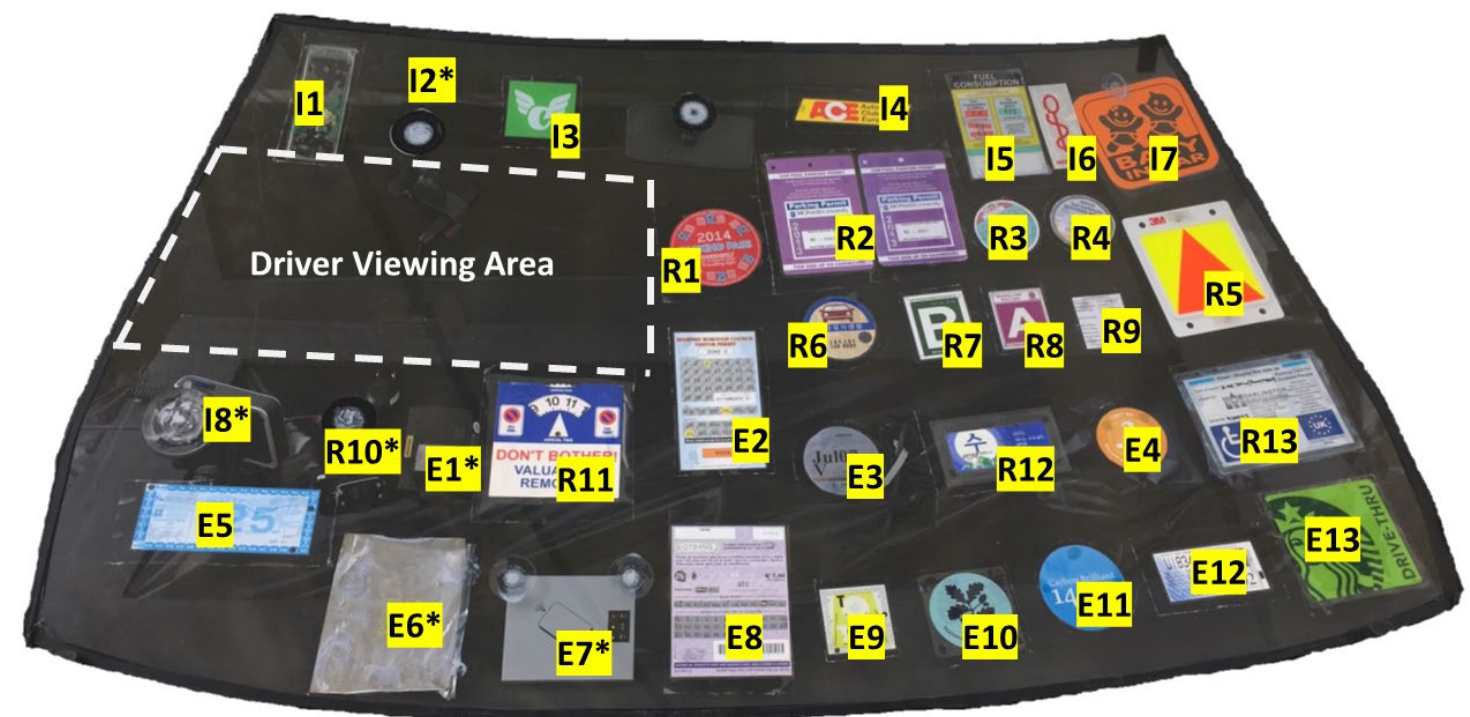

Figure 4: Artefacts labelled in line with the three primary categories. 
Some of the key characteristics of each of the artefacts applied on the windscreen are shown in Tables 1, 2 and 3 with particular attention paid to type of control, timeframe of application, degree of formality, and implementing agent (i.e. the body which manages automobility in that instance). Degree of formality refers to the level of which the item is held to comply with national/local rules or conventions with 5 being highly regulated or institutionalised (and 1 being the least formal, or most informal). In Figure 4 the use of an asterisk in the label $(*)$ denotes that the item is electronic or relies on some form of power; these items could also be deemed 'non-paper' based.

\subsection{Information based controls (I1 to I8)}

Eight artefacts were found to align to this category as they typically drew on measures that seek to remind, inform and educate the driver, other drivers, or other automobile linked stakeholders as to how they might alter certain aspects of their behaviour. These are described in the tables in this study where I1 refers to Information based control item number 1 (see Table 1). These artefacts are mainly informal which infers that the driver has displayed them in order to convey a signal or sign to others. Only the auto-club membership and fuel consumption label could be considered semiformal and formal respectively. Gössling (2017) notes in his survey of bumper stickers on vehicles that there are some 12 distinct categories and that all can be considered some form of expression of personality. Some artefacts shown here (baby on board, or I lift share) express similar meanings that he observed such as 'family status' or safety warning (p 61, ibid). Some of the objectives and categories in bumper stickers match those observed and catalogued here but bumper stickers are clearly item affixed by drivers/owners, whereas some windscreen artefacts are required through legislation or other means. Case's seminal work (1992) in this area used only 6 broad categories 
which align with Gössling's (2017) appropriately and these matches are outlined after Table 1.

Table 1: Informational artefacts characterised by six parameters. [TO BE INSERTED HERE]

The matches between Case's broad categories are listed here with Gössling's in brackets afterwards to demonstrate similarities: ideological/political [politics, advocacy], safety/public service [safety, family status], philosophical [religion, fun/humorous], commercial endorsement [advertisements], self-identity [advocacy, social status, sports, travel, self-reflection/control, personality] and other [fun/humorous, personality]. Baby on board (I7) seems to be a global expression and has persisted over a long period of time as Case cited 7 examples in his set of 1,518 (1992). Böhm et al (2006) highlight some natural facts which link directly to information items: these can be seen as 'stylish' self-evident embodiments which allow the driver to express various aspects of their individuality through (and on) the car itself.

\subsection{Regulatory controls (R1 to R13)}

The regulatory control items (13 in total) contrast with those artefacts which are informational (and informal) in nature; all but five can be considered formal. Formal regulatory artefacts are typically issued by the national government and are mandatory through some application of law. These items are summarised in Table 2.

Table 2: Regulatory artefacts characterised by six parameters. [TO BE INSERTED HERE] 
Regulation linked items deal mainly with the control of parking, or immobility of the vehicle, and also usage control by managing use through space, time, or fuel (see R7 and R8). Gössling (2017) notes that car use to alternate days by number plates is a prevalent practice in the past, for example in New Zealand in 1979 whilst similar schemes are widespread in South America and across many Chinese cities (Zhang, 2019); this is similar to R12 in Table 2. Both R7 and R8 are historical fuel rationing post-war time artefacts and the possibility of fuel shortages are highly relevant to a world of mobility which is sensitive to all forms of disruption such as strikes, blockades (Harman, 2002), extreme weather events, military conflict (Derber, 1943). Štitilis and Laurinaitis (2016) highlight critical legal issues with the use of 'dashcams' (dashboard cameras which store video material on small memory cards - see R10) and their rise in use, particularly in Russia (Lavrinc, 2013), where video evidence is used extensively to reduce staged vehicle accidents (which in many cases involve pedestrians) and/or to assist in solving disputes relating to road accidents. In the UK these items are being utilised to lower overall annual insurance premiums but in some cases the videos have the potential to end up on social media or elsewhere making the driver into a data manager (Štitilis and Laurinaitis, 2016) and may act as an impediment to personal privacy of those who were filmed, uploaded and viewed, typically without their consent. The implications for dashcam recordings and their subsequent fallout have yet to be fully felt throughout Europe but mobile recordings have the possibility to shape mobility and their underlying patterns and act in such a way as to be distinctly different to stationary surveillance.

\subsection{Economic controls (E1 to E13)}

The artefacts controlled by economic incentives or charges are mainly costs paid by the user for access to bridges, roads, parking, shared vehicles or specific places or 
zones. Only two artefacts displayed act as incentives to offers discounts to drivers either for consumer purchases (e.g. food and drinks in drive-through situations) or for having lower emitting vehicles emissions due to good driving practices. It should be noted that in many places ANPR (Automatic Number Plate Reader) systems have been used to regulate access to controlled zones and there are various arguments for and against both windscreen and number plate based systems (see scenarios in de Winter et al, 2019).

Table 3: Economic artefacts characterised by six parameters. [TO BE INSERTED HERE]

\subsection{Results and Discussion}

From this study, there are several observations that can be made from this process - these have emerged as part of the found object processes applied. First, it is noticeable that all the more technology-based (i.e. non-paper) artefacts are located about the driver (see Figure 3), and that they serve to apply dynamic or trip-level measures. As these items relay information which can change in real-time this location on the windscreen seems appropriate as these items need to relay information to the driver, rather than authorities, although E6 (a tolling device) needs to be electronically visible to the toll gantry. In our exhibit this toll tag is visible and can be made to be invisible by placing the mylar bag over the transponder for when the driver has high occupancy and is permitted to not pay the toll. Many of the other static artefacts are displaying a message to the outside world that for example permits parking or access to specific places. Referring to Böhm et al (2006) it is also relevant to consider their four key antagonisms of automobility: congestion, ecological sustainability, dependency on oil, and 'the invisible killing machine' (death through road traffic). Many of the artefact considered here attempt to reduce, or superficially address, the antagonisms such as 
congestion (E3, E8), sustainability (E7, E8, I3), oil dependency (E11, E12, R2, R7, R8, R12, I1, I5) and accidents (I7). Note that framed this way reduction in fuel use seems to be very prevalent in this set of examples with safety only marginally represented. If congestion were expanded to include parking controls, then control of 'place' and fuel use would be equally represented.

Second, information measures are applied by a whole range of stakeholders, whilst economic measures tend to be implemented either by private 'operators' or government agencies, and regulations are far more likely to be introduced by government bodies (with the exception of car parking regulations - see next point). The second point relates to the agent of the information artefacts which encompasses a wide range of bodies such as car club rescue services (i4, fuel companies and lift share users. The information is employed to signify status, such as 'I can be rescued if I break down', or in some cases sends a signal to other drivers such as this is a family car with children on board (I7 i.e. family status category/children information and safety/keep a safe distance, p.61, Gossling, 2017). Information displays attempt to inform, educate, and/or remind others of certain facts. As we note later there is a slight blurring of some categories.

Third car parking measures (a total of 7 in this sample) are clearly a major means of controlling car use for a whole range of agents and examples are found in all 3 instrument types but mainly in economic (E2, E10) and regulatory regimes $(\mathrm{R} 1, \mathrm{R} 2$, R11, R13). Parking space ownership is quite fragmented and operates at the micro-level in many countries meaning that many different bodies are involved in the management and control of parking. Although R13 (disabled parking badges) are primarily designed to allow closer access to those with declared disabilities, they also offer informational 
signals to other drivers which may signal - extra space required to unload devices (such as wheelchairs, ramps). Further to this some drivers also display bumper stickers stating phrases such as 'not every disability is visible' highlighting the recognition of unseen disabilities such as mental health, diabetes, etc. In this way a regulatory instrument is also informational. In Italy some autostrada toll tags, which are mainly economic instruments, also allow users to park in some private places whereby access is controlled by electronic barriers, thus fulfilling a role more like a regulatory instrument allowing paid access. The user or driver pays the fee automatically through an automatic payment system thus alleviating some hassles linked to using a bank card or allowing the driver to park more quickly. Some of the names of these devices also signal their intention; in the USA, turnpikes can be accessed using the E-ZPass (registered trademark) which can be used to pay for roads, bridges and tunnels. The gantries involved in these transactions promise higher speeds and reduced stress for drivers and users. Many other examples (a total of 8) grant access to public roads, or zones where cars are pro-actively controlled (E3, E4, E8) either to all cars (Italy, Malta - to reduce congestion and protecting the city) or to those which are most polluting (E4, and also UK ULEV Zone, London). Other restrictions by plate number (R12, Korea) or by more subtle means (R6, Japan). Payment for road use is clearly driven by economic instruments (E1, E5, E6, E9). Fourth, it would seem that whilst traditional measures have tended to be 'stick'-type measures which seek to control the motorist (regulatory artefacts in this study), the more recent measures look to offer 'carrots' or benefits to motorists - e.g. through better information or revenue for giving a lift or 'renting' one's vehicle. In this sample we observed there are more innovative measures in the economic instruments (E4, E6, E8, E12) as so called carrots, whereas the sticks perhaps only R10 (Russia, and other 
countries) could be considered an innovation. This finding seems to support the idea that incentives may be more prone to waves of innovation, and it may be prudent to consider what incentives may arise from the key components in smart mobility. Information based instruments could be seen as items that might nudge driver behaviour into certain directions and certainly many drivers use real-time traffic displays (I8) to re-route their journeys to avoid congestion or delays due to crashes, roadworks, etc. Fifth, all but one of the instruments on the windscreen could be categorised as social fixes in that individuals are being encouraged to consider their behaviour (Colney \& Tigar McLaren, 2009). One exception could be the fuel consumption label (I5), where there may be an indirect incentive for car manufacturers to improve the fuel economy of their vehicles however this can also exert influence on car purchases since this is proxy for expenditure on fuel as well as a marker of green credentials. As this could be viewed as specific message conveying 'be an advocate of the environment' as it also aligns with Gossling's bumper sticker categories (2017).

The artefacts selected to fit on the windscreen were purposefully influenced by the practical difficulties of obtaining and applying the artefacts, and it is acknowledged that it would have been possible to have arranged the instruments in a variety of other ways. It is important to remember that there are many additional policy tools used to control the motorist which do not involve any form of windscreen-based paraphernalia. It should be noted that many cordon or barrier entry schemes rely only on the traditional mechanism of handing over money through a window, whilst others rely on the licence plate providing a form of unique identification data.

Windscreens today are becoming less cluttered than in past years partly due to alternative media such as Automatic Number Plate Recognition (ANPR), GPS 
transponders and technologies becoming more flexible and affordable. Also there have been mounting concerns about the implications of drivers not having a sufficiently unobscured view of the road ahead to be able to drive safely. In October 2014 the UK stopped issuing vehicle licence (paper) discs and instead now monitors compliance via ANPR (Brignall, 2015). Indeed the UK license disc experience was initially problematic due to the losses incurred by those motorists not renewing their disc online, the increased clamping/enforcement, and the subsequent losses to treasury (estimated at $£ 80$ million) (Brignall, 2015). In summary, a plan which was meant to save the government $£ 10$ million ended up costing eight times more. For some countries the use of visible discs, stickers, vignettes, etc on windscreens may be around foreseeable future as a costeffective regulatory method. For other domains, the current paper-based and hardplastic technological clutter will likely be replaced by smart screens where embedded icons will represent licences and permits, and satnavs being replaced with integrated head up displays showing information about the journey and about what to expect at the destination. Increasing digitization, might create unforeseen hazards and digital clutter could become the norm.

In the future, new technological developments (SAE 2018, SAE J3016 ${ }^{\mathrm{TM}}$ ) will surely alter how traffic is managed in ways that we cannot currently foresee, though it is interesting to speculate using the five key components that Docherty et al (2018, p.118) set out were used to frame smart mobility, namely:

1) Mobility as a service models and the shift to a sharing economy more generally might presage a number of changes. Most obviously 'ownership' as characteristic is already being eroded by long term leaseholds of vehicles becoming more prevalent, but this would become even less anchored in the future. Leasehold and ownership more widely could be replaced by an 
environment dominated by usership relationships between car manufacturers, intermediators (such as mobility service providers) and the end customers. Vehicles could spend more less time being parked and more time on the road (in use) and this would rebalance the nature of the artefacts. Under this scenarios more artefacts signifying shared status such as liftshare (I3) and/or car pool parking permits (R2) could be expected to increase over time. Vehicle access control systems as used by car clubs/car sharing systems could be expected, whilst there might also be a reduction in more personalised occupant-related clutter such as baby on board (I7), or my family' style tags (Doyle \& Tranter, 2015), as well as probationary driving status (R5) or signs signifying doctor on call/person working in this area (I6). We might expect temporary parking to potentially reduce significantly if shared cars went back immediately into the system, but this would depend on the precise details of how the vehicles are utilised and the business model.

2) Increased digitalisation through user and sensor generated systems that provide 'big data' via continuous, real-time, and personalised systems will also change artefacts. Data storage, processing and capacity could also lead to changes in windscreen paraphernalia and black boxes could become commonplace. These could take the form of an all-in-one 'box' which in addition to digital image capture (R10) would provide GPS systems (I8) four route control/guidance and fully electronic toll ticket and parking could be expected (E1). These digital boxes, or simply digital fingerprints, could provide the functionality of many of other current paper based artefacts, such as E9, E7, E4, R11, R12, R13, and be more much integrated with the road infrastructure system and with other road users. 
3) The development of intelligent infrastructure whereby the transport infrastructure communicates directly to vehicles - would seem to point towards far more dynamic control mechanisms being possible. For example, the whole road network could potentially require drivers to use a satnav-based system to 'book' a path from an origin to a destination in advance of their trip, so maximising the potential of the whole network and minimising the risk of congestion and delays rather like aircraft or trains do currently. The described system would also lend itself to various forms of dynamic pricing, whereby motorists would be charged according to the 'cost' and/or level of demand of the path chosen.

4) The main impacts of decarbonisation on the artefacts represented will likely see fuel-related stickers (I1, fuel savings prompter; I5 consumption labels and others $-\mathrm{R} 8, \mathrm{E} 11, \mathrm{E} 4)$ simply to harmonise or potentially disappear if agreement is reached about what constitutes sustainable mobility. This is no direct solution here as noted by many others; Boussauw \& Vanoutrive (2017) show the major social injustices that result from targeting certain vehicle types and driving distances. They also note the monumental issues surrounding lack of progress in fuel consumption over time - which remains stubbornly fixed, globally. Gössling \& Cohen (2014) stress how policies typically fail, in the EU, due to ten major transport 'taboos'. Many of these taboos are deeply locked-in to the current system of both automobility(Gössling \& Metzler, 2017) , and aeromobility regimes and getting harmonious agreement on which policies and pathways to decarbonisation will be fraught with barriers to designing effective policies, and then getting the end-users to accept them (Gössling \& Cohen, 2014); finally the policies must be implemented. 
5) Autonomous vehicles present interesting challenges and opportunities in terms of traffic management (SAE, 2018) due to the implications on ownership that driverless cars might present. Why own a car if you can order some form of diala-pod taxi that will be affordable, arrive at your door within five minutes, and take you to where you need to go? (Enoch, 2015). These scenarios envisage a shift towards short term or trip-based 'user pay' controls rather than on those which are one-off and/or longer-term ownership-related. Pod transport would also presumably remove the need for driver qualifications and possibly even 'disabled people' categories (R13, R5), although these could conceivably be replaced by reputation grades based on user behaviour (punctuality, cleanliness, and so on) in a similar way Uber asks users to rate their drivers. All of these technological permutations have negative and positive effects and outcomes, and thus those planning future systems need to consider systemically. Autonomy also invites criticism as these imagined futures don't solve all the issues such as: inequality for those who can't access these new forms of mobility, even when completely free, may create issues (Boussauw \& Vanoutrive, 2017) or the personal attachment to the car (Gössling, 2017). Could it be that autonomy based futures whilst challenging the automobility dispositive, might actually reinforce some of the same policies and norms (Manderscheid, 2014)? There does seem to be evidence in that trajectory, with peri-urban regions remaining glued to the automobile and that widespread electrification may also make the internal combustion powertrain more resilient in the contest for distance. 
The aim of this paper was to explore how car ownership and use are controlled through informational, regulatory and economic instruments in the present day and to speculate on how traffic may be mapped in the future. The artefacts demonstrate, physically and visually, how public policy instruments and measures can be categorised according to type (via coercion, economic assets and normative values), through regulation, economic incentives and information. Each item can be framed by the aspect being targeted (the vehicle or occupant), and on how this might be done - whether on ownership, parking or usage - and the frequency and longevity of these interventions. It is also useful to consider the agents and routes through which a policy measure is applied, and on whether it acts predominantly on the demand or the supply. For the future, in focusing on the windscreen it is probably the case that the current paper-based and hard-plastic technological clutter will (very) soon become obsolete particularly in countries where digital forms of mobility control are prevalent and accepted. Instead, it is the view of the authors that windscreens are set to become smart screens with the stuck-on artefacts likely being replaced with embedded icons to represent licences and permits, and with satnavs being replaced with integrated head up displays showing information about the journey and about what to expect at the destination. Indeed, on similar lines technology manufacturer Garmin previously produced a \$US150 HUD (head up display) projection unit that sits on the dashboard and beams speed and other navigation-related information onto a photo-sensitive film stuck onto the windscreen. As of 2019 these units cost $\$ 70$ US. BMW vehicles for instance, now provide screens that host a range of car-appropriate 'apps' that will likely perform similar functions in the future. There is much rhetoric about the inexorable shift towards intelligent infrastructure and vehicle systems underpinned by big data and analytical models in the future seems to indicate that the perceived reality of the so- 
called 'freedom of the road' will continue to disappear in the (similarly doomed) rear view mirror as motoring becomes steadily less free by ever more varied and sophisticated means. The current regime of automobility may (hopefully) be replaced with a transport system that is more effective, efficient and more accessible to all than what currently exists (Dant, 2017) but there are significant barriers to overcome (Boussauw \& Vanoutrive, 2017; Gössling \& Cohen 2014; Manderscheid, 2014). A similar paradox is revealed by Docherty et al $(2018, p .118)$ that called the smart mobility framing as something that promises "a system that reduce demand, whilst at the same fulfilling previously unmet demand and creating new demand.” There is also the distinct possibility that windscreens could disappear completely if fully autonomous automobility becomes a possible future pathway. Windscreens could end up being replaced by more inexpensive alternatives such as interior panels which could be padded for comfort and protection next to more screens especially if the ever-present screen/screen time paradigm continues. This future as predicted by Dant (p 368), evolves in such a way that 'all drivers [turn] into passengers'. The shift in driver/passenger is then potentially accompanied by the shift of car towards a mobile office/living space/bedroom as depicted by Hitti (2018). What is less easy to predict is how disruptive these technologies and their associated practices in mobility will play out with respect to the automobility system (Urry, 2004) which places the automobile as a core within the extended system.

\subsection{Acknowledgements}

The authors would like to acknowledge the individuals and organisations for their help in sourcing artefacts donated to this study. In particular, we thank: Betty Deakin, Peter Kerr, , Chris de Gruyter, Kerstin Leder-Mackley, Maria Attard, Barathi Rajendra, Bavesh Doshi, Christopher Walton, Jennifer O’Brien, Maria-Ioanna Imprialou, 
Paraskevi Michalaki, Ayako Taniguchi, Garrath Willson, Mark Harrod, James Warren,

Ann Enoch, Royland Enoch, Sudaxshina Murdan, Anjani Murdan, Anshu Murdan,

Tony Smith-Howell, Kirti Ruikar, Luise Jungs and Christian Melles, Lisa Davison,

Adam Millard-Ball, Pauline Jones, Afendi Dahlan, Ellie Boxall Julia Hatch, and

Swastee Matabadul. The authors also thank both referees for their contribution which

has significantly improved the final text.

\section{References}

Böhm S, Jones C, Land C, Paterson M (2006) Introduction: Impossibilities of automobility, in Against Automobility, Blackwell Publsihing, Oxford, UK, pp 116.

Boussauw, K and Vanoutrive T (2017) Transport policy in Belgium: Translating sustainability discourses into unsustainable outcomes, Transport Policy, 53, 1119.

Brignall, M (2015) Ministers lose $£ 80 \mathrm{~m}$ in revenue after scrapping car tax discs, The Guardian, 25 November. Visit https://www.theguardian.com/money/2015/nov/26/ministers-lose-80-millionrevenue-after-scrapping-car-tax-discs. Last accessed 24 October 2019.

Case C E (1992) Bumper stickers and car signs ideology and identity Journal of Popular Culture; 1992; 26 (3), 107-119.

Chamon M, Mauro P and Okawa Y (2008) Mass car ownership in the emerging market giants, Economic Policy, 23, 243-296.

Chan N D and Shaheen S A (2012) Ridesharing in North America: Past, present, and future, Transport Reviews, 32(1), 93-112.

Chilvers I \& Glaves-Smith J (2015) Objet trouvé, Oxford Dictionary of Modern and Contemporary art, $3^{\text {rd }}$ edition, Oxford University Press, online version, https://www-oxfordreferencecom.libezproxy.open.ac.uk/view/10.1093/acref/9780191792229.001.0001/acref9780191792229-e-1993

Colney J and Tigar McLaren A (2009) 'Introduction' in, Car Troubles, Critical Studies of Automobility and Auto-Mobility, Ashgate Publishing, Surrey, UK, 1-17.

Dant T (2017) Drivers and Passengers (Chapter 35) the Routledge Handbook of Mobility, (eds.), Adey P, Bissell D, Hannam K, Merriman P and Sheller M., Routledge, Oxford, UK, 367-375.

Dennis K and Urry J (2009) After the car, Polity Press, London, UK

Department for Transport (Great Britain) (2007) The Blue Badge Scheme: Rights and Responsibilities in England, Crown Copyright, London.

Derber M (1943) Gasoline Rationing Policy and Practice in Canada and the United States, Journal of Marketing, 8(2), 137-144.

Docherty I, Marsden G, Anable J (2018) The governance of smart mobility, Transport Research A 115, 114-125.

Dodds A (2013) Comparative public policy, Palgrave Macmillan, London. 
Dossman A (2008) Socialist Highways? Approaching the Autobahn in the GDR, (eds. Mauch C \& Zeller T) The World Beyond the Windshield - Roads and Landscapes in the United States and Europe, Ohio University Press, Athens, Ohio, 143-167.

Douglas M J, Watkins S J, Gorman D R, Higgins M (2011) Are cars the new tobacco? Journal of Public Health, 33(2), 160-169.

Doyle K and Tranter K (2015) Automobility and 'My Family' stickers, Continuum, 29:1, 70-83, DOI: 10.1080/10304312.2014.968524

Enoch M P (2012) Sustainable transport, mobility management and travel plans, Ashgate, Farnham.

Enoch M P (2014) Categorising car parking spaces and policies, Traffic Engineering and Control, 55(1), March, 37-39.

Enoch M P (2015) How a Rapid Modal Convergence into a Universal Automated Taxi Service could be the Future for Local Passenger Transport, Technology Analysis and Strategy Management, 27(8), 910-924.

Etizoni A (1961) A comparative analysis of complex organisations: Involvement, their power and their correlates, Free Press, New York.

Gössling S (2017) The Psychology of the Car: Automobile Admiration, Attachment and Addiction, Elsevier, Amsterdam, Netherlands.

Gössling, G and Cohen S (2014) Why sustainable transport policies will fail: EU climate policy in the light of transport taboos, Journal of Transport Geography, 39, 197-207

Gössling, G and Metzler D (2017) Germany's climate policy: Facing an automobile dilemma, Energy Policy, 105, 418-428

Harman R (2002) Fuel tax rationing and fuel protests: An historical perspective, (in ed. Lyons $\mathrm{G}$ and Chatterjee K), Transport Lessons from the Fuel Tax Protests, Chapter 1, pp.3-26, Ashgate, Farnham.

Harrison C and Wood P (2002) Art in Theory 1900-2000: An Anthology of Changing Ideas, Wiley-Blackwell; New York, USA

Hitti N (2018) Space10 envisions future of self-driving cars as farms, hotels and clinics on wheels, dezeen, 19 September. Visit https://www.dezeen.com/2018/09/19/space10-envisions-future-of-self-drivingcars-as-a-farm-hotel-or-clinic-on-wheels/. Last accessed 24 October 2019.

KhakZand M and Babaei S (2018) Developing a New Method for the Architectural Design Process: An Experimental Study Using Found-Object Art in the Design Studio, The Design Journal, 21:2, 209-225, DOI: $10.1080 / 14606925.2018 .1429368$

Lavrinc D (2013) Why Almost Everyone in Russia Has a Dash Cam, Wired, 15 Februry. Visit http://www.wired.com/2013/02/russian-dash-cams/. Accessed on 19 June 2014.

Ledbury M, Miller N, Lee A, Fairman T and Clifton C (2006) Understanding policy Options, Home Office, London.

Lloyd M and Fourt-Wells S (2018) Stickers on cars: a note on 'My Family' decals, Continuum, 32:2, 201-212, DOI: 10.1080/10304312.2017.1395808

Manco T (2012) Raw + Material = Art: Found, Scavenged, and Upcycled, Thames and Hudson Ltd., London

May A D (1986) Traffic restraint: a review of the alternatives, Transportation Research A, 20(2), 109-121. 
Mauch C \& Zeller T (2008) The World Beyond the Windshield - Roads and Landscapes in the United States and Europe, Ohip University Press, Athens, Ohio.

Manderscheid K (2014) The Movement Problem, the Car and Future Mobility Regimes: Automobility as Dispositif and Mode of Regulation, Mobilities, 9:4, 604-626, DOI: $10.1080 / 17450101.2014 .961257$

Morse, M. (1998) Virtualities television, media art, and cyberculture. Indiana University Press.

Nitch-Smith M (2016) The number of cars worldwide is set to double by 2040, Business Insider, 22 April. Visit https://www.weforum.org/agenda/2016/04/the-numberof-cars-worldwide-is-set-to-double-by-2040. Last accessed 24 October 2019.

Rydin, Y., A. Bleahu, M. Davies, J. Dávila, S. Friel, G. De Grandis, N. Groce, P. C. Hallal, I. Hamilton, P. Howden-Chapman, K-M. Lai, C. J. Lim, J. Martins, D. Osrin, I. Ridley, I. Scott, M. Taylor, and P. Wilkinson. (2012). Shaping cities for health: complexity and the planning of urban environments in the 21 st century. Lancet Commission on Cities and Health. The Lancet, 379 (June 2012): 20792108.

SAE International (2018) Levels of Driving Automation (SAE J3016 ${ }^{\mathrm{TM}}$ ). Visit https://www.sae.org/news/press-room/2018/12/sae-international-releasesupdated-visual-chart-for-its- $\%$ E2\%80\%9Clevels-of-drivingautomation $\% \mathrm{E} 2 \% 80 \% 9 \mathrm{D}$-standard-for-self-driving-vehicles. Last accessed 24 October 2019.

Santos G, Berhrendt H and Teytelboym A (2010) Part II: Policy instruments for sustainable road transport, Research in Transportation Economics, 28, 46-91.

Santos G, Berhrendt H, Maconi L, Shirvani T and Teytelboym A (2010) Part I: Externalities and economic policies in road transport, Research in Transportation Economics, 28, 2-45. https://doi.org/10.1016/j.retrec.2009.11.0

Shaheen S A and Cohen A P (2013) Carsharing and Personal Vehicle Services: Worldwide market developments and emerging trends, International Journal of Sustainable Transportation, 7, 5-34.

Spencer D (2002) Found object art, Schiffer Publishing Ltd., Atglen, PA, USA

Stitilis D and Laurinaitis M (2016) Legal regulation of the use of dashboard

cameras: Aspects of privacy protection, Computer Law \& Security Review 32, 316326.

Swiss Federal Customs Administration (2020) Affixing the motorway charge sticker to the vehicle, Motorway charge sticker - other important information

https://www.ezv.admin.ch/ezv/en/home/information-individuals/documents-fortravellers-and-road-taxes/motorway-charge-sticker--vignette-/motorway-chargesticker--other-important-information.html

TSO (2010) The Stationary Office, View to the front and windscreen obscuration

(Published 1 May 2010) https://www.gov.uk/government/publications/stickers-or-otheritems-in-front-and-rear-windscreens/view-to-the-front-and-windscreenobscuration

Urry J (2004) The System of Automobility, Theory, Culture \& Society 21(4/5): 25-39. https://doi.org/10.1177/026327640404605

Vedung E (1998) Policy instrument, typologies and theories, (in ed. Bemelmans-Videc M L, Rist R C and Vedung E) Carrots, sticks and sermons: Policy instruments and their evaluation, Transaction, London, 21-58.

Waldman D (1992) Collage, Assemblage and the Found Object, Phaidon Press Ltd, London. 
de Winter JCF, Dodou D, Happee R and Eisma YB (2019) Will vehicle data be shared to address the how, where, and who of traffic accidents? European Journal of

Futures Research 7:2 https://doi.org/10.1186/s40309-019-0154-3

Zhang J (2019) Driving towards modernity: cars and the lives of the middle class in contemporary China, Cornell University Press, NY, USA

Table 1, 2, 3 are shown below

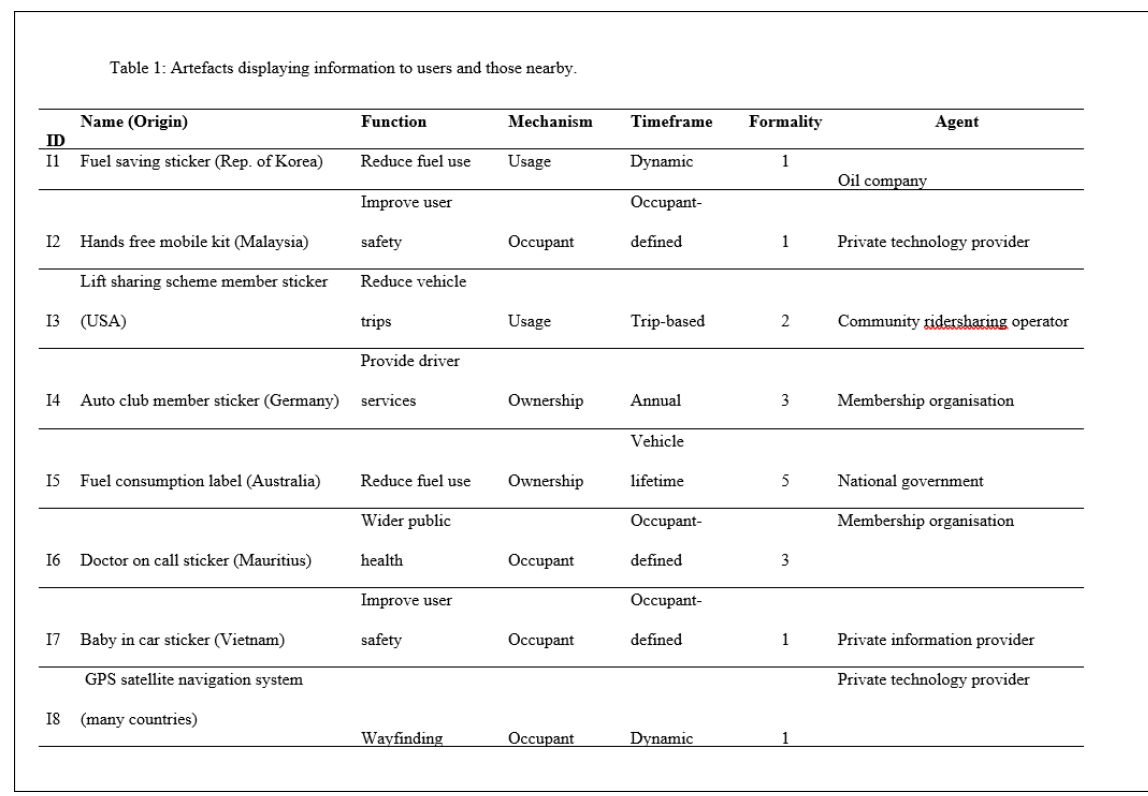

\begin{tabular}{|c|c|c|c|c|c|c|}
\hline ID & Name (Origin) & Function & Mechanism & Timeframe & Formality & Agent \\
\hline R1 & Event parking pass (UK) & $\begin{array}{l}\text { Improve } \\
\text { accessibility }\end{array}$ & Parking & $\begin{array}{l}\text { Less than } \\
\text { weekly }\end{array}$ & 3 & Visitor attraction \\
\hline $\mathrm{R} 2$ & $\begin{array}{l}\text { Car pool parking permit } \\
\text { (Australia) }\end{array}$ & $\begin{array}{l}\text { Encourage lift } \\
\text { sharing }\end{array}$ & Parking & Annual & 3 & Employer \\
\hline R3 & Motor tax disc (Ireland) & $\begin{array}{l}\text { Control access } \\
\text { to roads }\end{array}$ & Ownership & Annual & 5 & National government \\
\hline R4 & $\begin{array}{l}\text { MOT disc (Northern } \\
\text { Ireland) }\end{array}$ & $\begin{array}{l}\text { Improve } \\
\text { vehicle safety }\end{array}$ & Ownership & Annual & 5 & Sub-national government \\
\hline R5 & $\begin{array}{l}\text { Probationary driving } \\
\text { mark (Singapore) }\end{array}$ & $\begin{array}{l}\text { Improve road } \\
\text { safety }\end{array}$ & Occupant & $\begin{array}{l}\text { One year } \\
\text { after test }\end{array}$ & 5 & National government \\
\hline R6 & $\begin{array}{l}\text { Garage certificate } \\
\text { (Japan) }\end{array}$ & $\begin{array}{l}\text { Improve } \\
\text { accessibility }\end{array}$ & Parking & $\begin{array}{l}\text { Vehicle } \\
\text { lifetime }\end{array}$ & 5 & Regional police service \\
\hline R7 & $\begin{array}{l}\text { Mileage rationing sticker } \\
\text { (USA) }\end{array}$ & $\begin{array}{l}\text { Reduce fuel } \\
\text { use }\end{array}$ & Usage & Annual & 5 & National government \\
\hline R8 & $\begin{array}{l}\text { Gasoline rationing } \\
\text { sticker (Canada) }\end{array}$ & $\begin{array}{l}\text { Reduce fuel } \\
\text { use }\end{array}$ & Usage & Annual & 5 & National government \\
\hline R9 & $\begin{array}{l}\text { Insurance vignette } \\
\text { (Mauritius) }\end{array}$ & $\begin{array}{l}\text { Ensure } \\
\text { vehicles } \\
\text { insured }\end{array}$ & Ownership & Annual & 5 & National government \\
\hline R10 & $\begin{array}{l}\text { Dashboard camera } \\
\text { (Russia) }\end{array}$ & $\begin{array}{l}\text { Improve user } \\
\text { security }\end{array}$ & Usage & Dynamic & 1 & Private technology provider \\
\hline R11 & $\begin{array}{l}\text { Visitor parking disc } \\
\text { (UK) }\end{array}$ & $\begin{array}{l}\text { Improve } \\
\text { accessibility }\end{array}$ & Parking & Trip-based & 5 & Local authority \\
\hline R12 & $\begin{array}{l}\text { Restriction based on } \\
\text { license plate number } \\
\text { (Rep. of Korea) }\end{array}$ & $\begin{array}{l}\text { Reduce vehicle } \\
\text { use }\end{array}$ & Usage & $\begin{array}{l}\text { One day a } \\
\text { week }\end{array}$ & 4 & Employer \\
\hline R13 & $\begin{array}{l}\text { Blue badge scheme } \\
\text { permit (UK) }\end{array}$ & $\begin{array}{l}\text { Improve } \\
\text { personal } \\
\text { access }\end{array}$ & Occupant & $\begin{array}{l}\text { Occupant- } \\
\text { defined }\end{array}$ & 5 & Local authority \\
\hline
\end{tabular}




\begin{tabular}{|c|c|c|c|c|c|c|}
\hline ID & Name (Origin) & Function & Mechanism & Timeframe & Formality & Agent \\
\hline E1 & Electronic tag toll ticket (Malaysia) & $\begin{array}{l}\text { Access toll } \\
\text { road }\end{array}$ & Usage & Trip-based & 5 & Toll road operator \\
\hline E2 & Visitor pay-and-display parking (UK) & $\begin{array}{l}\text { Access } \\
\text { parking }\end{array}$ & Parking & Trip-based & 5 & Local authority \\
\hline E3 & Supplementary licence disc (Malta) & $\begin{array}{l}\text { Access city } \\
\text { centre }\end{array}$ & Usage & Annual & 5 & National government \\
\hline E4 & Emissions-based fee (France) & $\begin{array}{l}\text { Access city } \\
\text { centre }\end{array}$ & Usage & Vehicle lifetime & 5 & National government \\
\hline E5 & Highway toll ticket (Thailand) & $\begin{array}{l}\text { Access toll } \\
\text { road }\end{array}$ & Usage & Trip-based & 5 & Toll road operator \\
\hline E6 & Electronic tag toll ticket shield (USA) & $\begin{array}{l}\text { Access toll } \\
\text { road }\end{array}$ & Usage & Trip-based & 3 & Toll road operator \\
\hline E7 & $\begin{array}{l}\text { Vehicle access control system } \\
\text { (Germany) }\end{array}$ & $\begin{array}{l}\text { Access } \\
\text { carsharing car }\end{array}$ & Usage & Trip-based & 4 & Carsharing operator \\
\hline E8 & Traffic limiting permit (Italy) & $\begin{array}{l}\text { Access city } \\
\text { centre }\end{array}$ & Usage & One day & 5 & Local authority \\
\hline E9 & Motorway toll vignette (Austria) & $\begin{array}{l}\text { Access toll } \\
\text { road }\end{array}$ & Usage & Less than annual & 5 & Toll road operator \\
\hline E10 & National Trust (UK) & $\begin{array}{l}\text { Access } \\
\text { parking }\end{array}$ & Parking & Annual & 4 & Charity \\
\hline E11 & Emissions offset sticker (UK) & $\begin{array}{l}\text { Minimise } \\
\text { carbon levels }\end{array}$ & Usage & Annual & 3 & Not for profit \\
\hline E12 & National mileage tax (New Zealand) & $\begin{array}{l}\text { Manage road } \\
\text { damage }\end{array}$ & Usage & Annual & 5 & National government \\
\hline E13 & Customer loyalty sticker (Malaysia) & $\begin{array}{l}\text { Incentivise } \\
\text { custom }\end{array}$ & Occupant & $\begin{array}{l}\text { Occupant- } \\
\text { related }\end{array}$ & 2 & Retailer \\
\hline
\end{tabular}

